\title{
Industry level analysis: the way to identify the binding constraints to economic growth
}

\section{Vincent Palmade*/}

\begin{abstract}
There are many economic diagnostic tools available which are trying to identify the constraints to economic growth in a given country. Unfortunately these tools tend to provide inconclusive and often conflicting answers as to what the most important constraints are. Even more worrisome, they tend to overlook the many industry specific policy and enforcement issues which, collectively, have been found to be the most important constraints to economic growth. This is the key finding from more than ten years of economic research by the McKinsey Global Institute (MGI). The MGI country studies have been uniquely based on the in-depth analysis of a representative sample of industries where clear causality links could be established between factors in the firms' external environment and their behavior, in particular through the analysis of competitive dynamics. They showed in details how industry specific policy and enforcement issues were the main constraints to private investment and fair competition - the two drivers of productivity and thus economic growth. This finding implies that governments and international financial institutions should rely much more on in-depth industry level analysis to uncover product market competition issues and set reform priorities. These analyses should include the often overlooked but critically important domestic service sectors such as retail and housing construction.
\end{abstract}

Key terms: growth, industry, product market, competition, investment and productivity

*/ Lead Economist at FIAS, a joint facility of the World Bank and IFC, and former Partner of the McKinsey Global Institute

World Bank Policy Research Working Paper 3551, March 2005

The Policy Research Working Paper Series disseminates the findings of work in progress to encourage the exchange of ideas about development issues. An objective of the series is to get the findings out quickly, even if the presentations are less than fully polished. The papers carry the names of the authors and should be cited accordingly. The findings, interpretations, and conclusions expressed in this paper are entirely those of the authors. They do not necessarily represent the view of the World Bank, its Executive Directors, or the countries they represent. Policy Research Working Papers are available online at http://econ.worldbank.org. 
Figure 1. Sectors and Countries Studied by MGI between 1990 and 2003
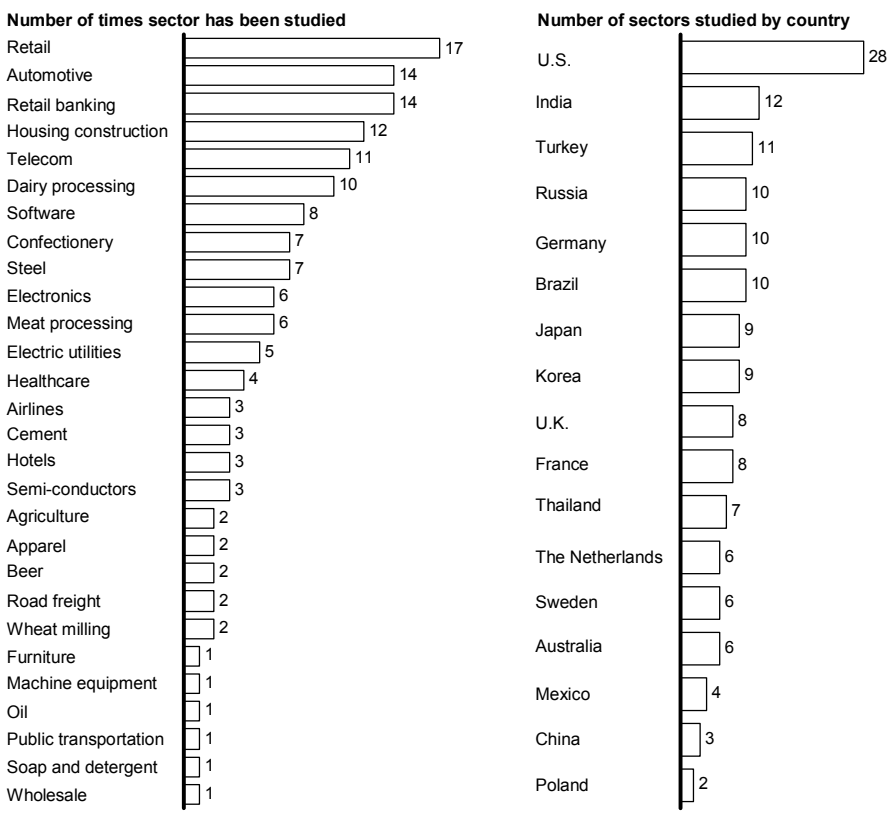

MGI related

government studies

- Portugal

- Dubai

- Philippines

- Argentina

ASEAN

Figure 2. Main Finding of MGI Studies

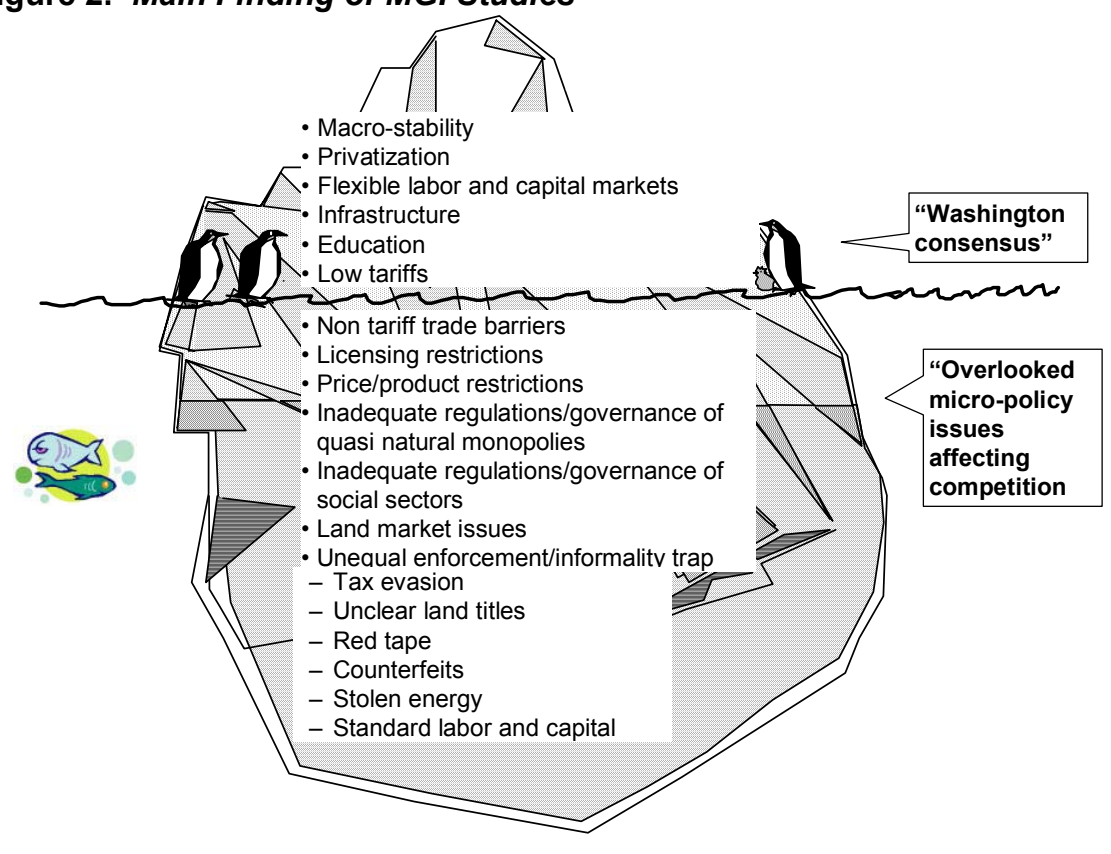




\section{INTRODUCTION AND ACKNOWLEDGEMENT}

This short paper synthesizes the key findings and methodology of the McKinsey Global Institute (MGI) as they relate to developing countries. The views expressed in this paper are solely mine while most of the facts are from MGI studies.

Since 1990, the MGI has conducted 17 studies of developed and developing countries, spanning 28 economic sectors (Figure 1). All the MGI studies are entirely financed by McKinsey and can be accessed fully and freely at mckinsey.com/mgi. The Power of Productivity, by William Lewis, the founding Director of MGI between 1990 and 2001, also synthesizes the results. The work of the Institute continues under the leadership of Diana Farrell, Director since 2002.

One country study typically took a year for a full-time research team of 10 people, and required more than 400 in-depth company interviews. The findings have been extensively reviewed by world-class economists to ensure that the fact base and economic reasoning met the highest academic standards. Robert Solow chaired a majority of the Institute's Academic Advisory Committees. Olivier Blanchard, Martin Baily, Dick Cooper, Dani Rodrik, Montek Ahluwalia and Leszek Balcerovicz also made important contributions.

The first section of this paper presents the findings and the second presents the methodology used in the studies.

\section{PRODUCT MARKET COMPETITION: THE ENGINE OF GROWTH}

Good macroeconomic policies, particularly fiscal discipline and private ownership, are necessary but not sufficient conditions for strong economic performance. Now that most developing countries have made significant progress on macroeconomic stabilization and privatization, MGI found that micro policy issues affecting product market competition are collectively the most significant impediments to faster economic growth. Unfortunately, most of the public debates and the governments' energy remain too centered on macroeconomic policies, distortions in the capital and labor markets, lack of labor skills and infrastructure (Figure 2).

Micro policy issues, e.g., restrictions to foreign direct investment or unequal enforcement of taxes between formal and informal players, have been found to be critical because they determine the level and fairness of competition. Competitive pressure is what forces managers to get their company to its productivity potential a result also obtained by the Investment Climate Surveys of the World Bank. In fact, the studies showed that most managers are not profit maximizers (increasing productivity is hard work). 
Figure 3. Results from India Study GDP growth, CAGR

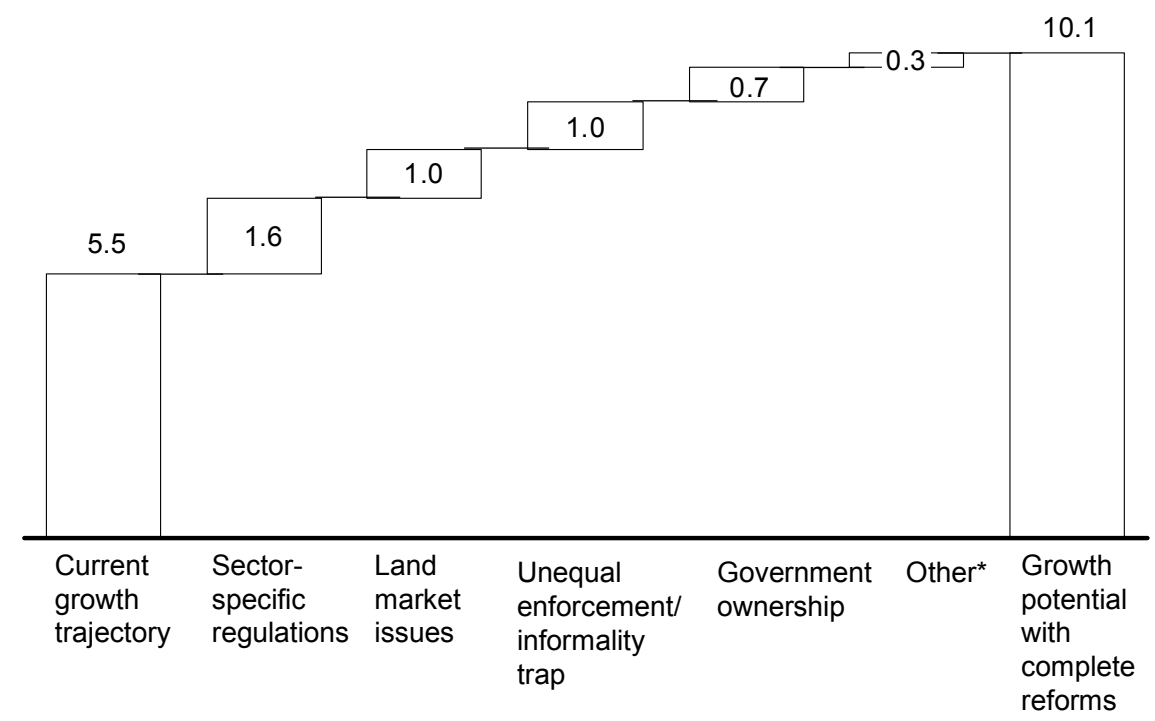

* Labor market, education, infrastructure

Source: McKinsey Global Institute

Figure 4. Comparison of Sector Productivities in India

Productivity, U.S. $=100$
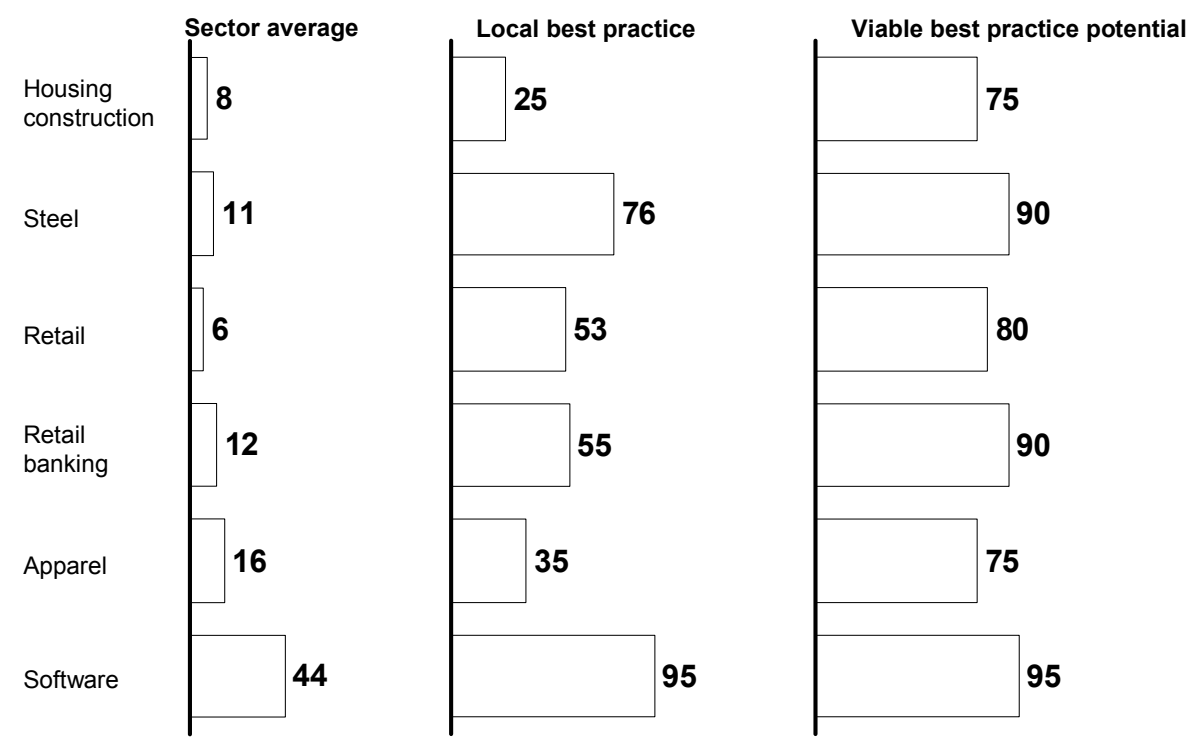

Source: McKinsey Global Institute 
Competitive pressure moves up and down value chains through sector linkages: retailers influence the performance of wholesalers and food processors which in turn drive the performance of the agriculture sector (e.g. contract farming), call centers require a high performing telecom industry, real estate developers influence the performance of the construction material industry and vice versa.

Product market competition is the main capital allocation mechanism - retained earnings are in most countries the main source of financing. It is thus essential that the most profitable companies are also the most productive which is what happened in intense and fair competitive markets. Competition also forces companies to invest to keep up with operational best practices.

The studies have shown that managers under intense competitive pressure are quick to find ways to go around labor market rigidities - e.g. Indian state-owned steel plants have relied on voluntary retirement schemes to reduce their excess labor. Competition is also forcing companies to invest in training their workers.

Finally, international and local competitive pressure is what drives national and local governments (often under the pressure of the private sector) to address some of the investment climate issues in the exposed sectors - e.g. Andhra Pradesh reformed its power sector in part because its manufacturers were under increase pressure from imports following India's reduction in import tariffs. This is why lowering barriers to trade and FDI is probably the best way for countries to get started on the reform agenda.

Unfortunately, most sectors are not exposed to international competition and many of the microeconomic policy issues affecting them never make it to the radar screen of reformers. For example, MGI showed that these overlooked micro policy issues cost India more than 3 percentage points of annual GDP growth (Figure 3).

These GDP growth rate estimates are based on the generalization of very detailed industry level analysis to systematically identify and assess the factors leading to low investment and/or productivity (see the second section for a detailed presentation of the methodology). Going back to the India example, MGI found in most sectors a wide labor productivity distribution between the average performer, the local best practice and what MGI estimated to be the viable potential given the prevailing factor costs. Most of these productivity gaps could be traced back to micro policy issues distorting competition within India and/or shielding Indian companies from international best practices - the software sector being the exception confirming the rule (Figure 4).

We group these overlooked micro policy issues into three categories: sector specific policy issues, land market issues and the unequal enforcement/informality trap. 


\section{Industry-Specific Policy Issues}

There are two main types of industry-specific policy issues: a) industry policies restricting competition and investment; and b) poor attempts at policing quasi natural monopolies and social sectors.

\section{Sector policies restricting competition and investment}

- Restrictions on FDI. Despite the growing consensus on the positive impact of FDI, most developing countries continue to forbid FDI in many sectors - e.g. no FDI allowed in the Indian retail sector. MGI found that the impact of FDI is the strongest in sectors with intense and fair competition and strong inter-linkages with supplier and user industries. This is what happened in the Indian automotive sector where productivity more than tripled following the arrival of FDI. Combined with increased competitive pressure, this led to rapidly declining prices resulting in output growing even faster with a net employment gain (Figure 5). Policies that have attempted to force spillover effects from FDI such as local content and joint venture requirements have often proven counter-productive by restraining competition or leading to subscale investments (e.g., the consumer electronic sector in India).

- Other licensing restrictions. Entry may be restricted to domestic investors as well. India, for example continues to reserve the production of more than 600 manufacturing products to small-scale companies in the ill founded belief that it will be good for employment. In fact, this licensing regime cost India many jobs by preventing it to be competitive - e.g. against China in the apparel sector (figure 6). The negative impact of licensing can be more subtle. For example, agency laws in the Middle East prevent large productive retailers from negotiating discounts (justified by scale economies) with monopoly importers while small informal retailers rely on "parallel" imports to go around the fat margins of agents. This results in these low-productivity retailers enjoying $15 \%$ lower cost of goods sold than their productive competitors - the reverse of a fair market outcome. The removal of such restrictions has had dramatic positive impact on productivity and investments, e.g. the rise in competition and decline in prices occurring in the mobile telephony industry around the world. 
Figure 5. Removal of Product Market Barriers Led to Dramatic Growth in the Indian Automotive Industry

Index: India = 100 in 1992-93

$$
\begin{aligned}
& \text { Labor } \\
& \text { productivity }
\end{aligned}
$$

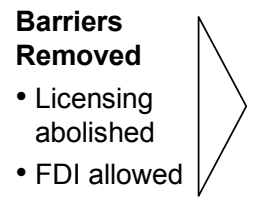

Source: McKinsey Global Institute

$$
\text { Output }
$$

Employment

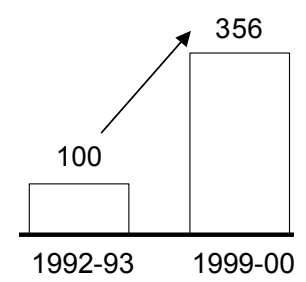

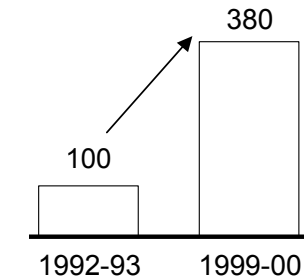

1999-00

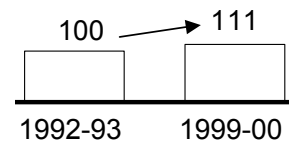

Figure 6. Product Market Barriers Hamper the Efficiency of the Indian Apparel Industry

Barriers
$\begin{aligned} & \text { - Small-scale industry } \\ & \text { reservation in apparel and } \\ & \text { textile } \\ & \text { - Non-level excise duties on } \\ & \text { textiles }\end{aligned}$
- Red tape in customs




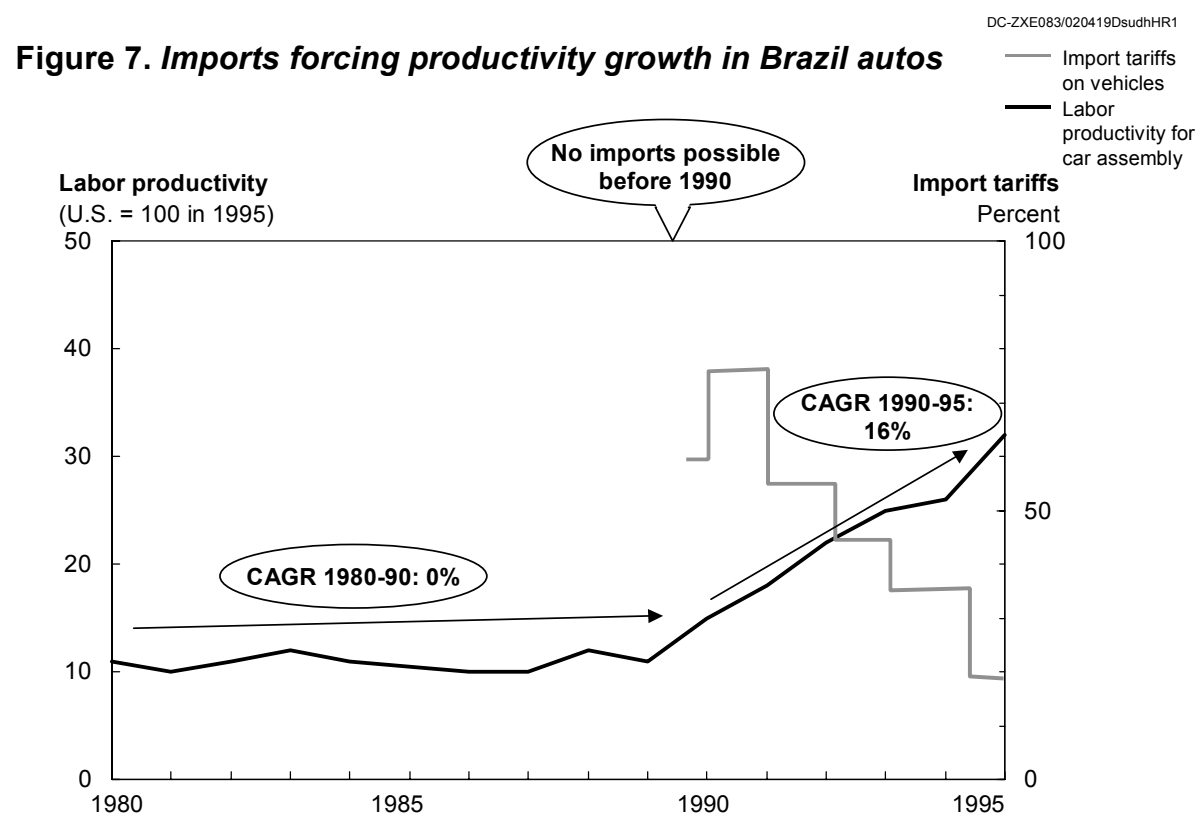

Source: McKinsey Global Institute

Figure 8. Impact of Tariff and Non-Tariff Trade Barriers on Prices

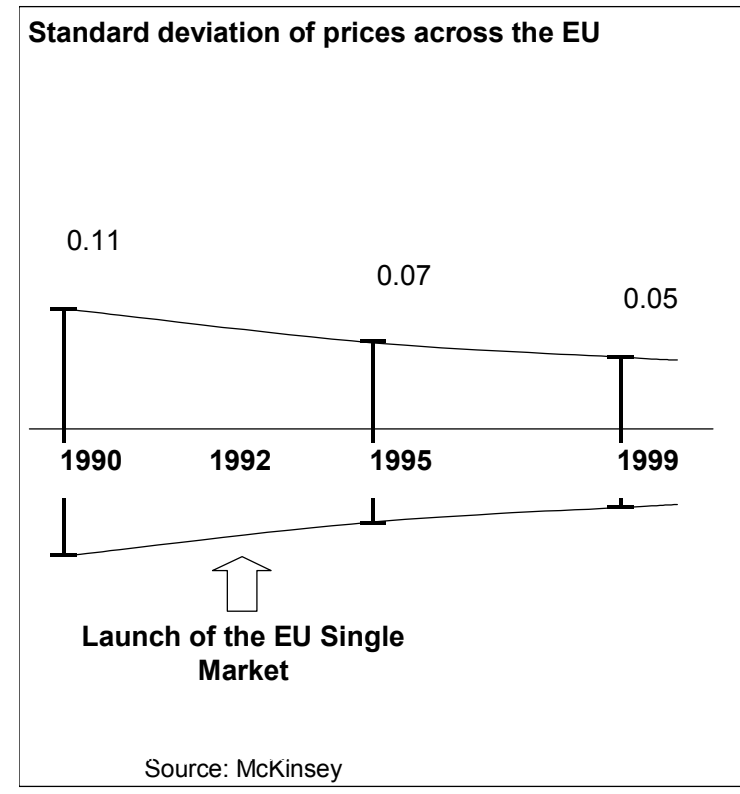

\section{Standard deviation of prices in ASEAN and US}

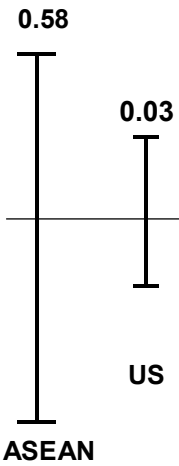


- Trade barriers (including non tariffs). Like many others, MGI found many examples of the positive impact of lower trade barriers. For example, labor productivity shot up in the Brazilian automotive industry after imports were allowed (Figure 7). Although most countries have been lowering their tariffs steadily, many non tariff trade barriers have popped up (e.g., cumbersome technical standards, custom and fiscal discrimination). It is non tariff trade barriers that limit cross country competition in the consumer good industries across ASEAN, resulting in very large price discrepancies (Figure 8).

- Restrictions on prices, products and services. Such restrictions often limit the capacity for more productive companies to compete on price and/or new services. For example, pricing regulations in trucking have limited competition and productivity in Western Europe until they were dismantled by the EU. short retail opening hours in Germany protect the low-productivity city center retailers from high- productivity suburban competitors.

\section{Poor attempts at policing quasi natural monopolies and social sectors -}

"The cure is often worse than the disease".

- Quasi-natural monopolies. Up to $10 \%$ of a country's economy consists of sectors that are quasi natural monopolies, in the sense that they require large one-off investment. This is typically the case for large network infrastructure such as electricity distribution, local fixed telephony, oil pipelines, water distribution, roads and airports. In such cases, intense competition can hardly be expected since it would lead to overcapacity and to huge financial losses for the new entrants. The historical remedy to this problem has been government ownership and control of the assets. This led to many well understood management/ governance problems that have been compounded by non economic pricing regulations (often in the pursuit of social objectives), often with detrimental economic effects. Subsidized power and water prices have discouraged private investments due to a lack of trust in the government's capacity to pay back the subsidy. This has forced companies to rely on their own much more expensive generators and forced low-income households to rely on very expensive informal sources of water, while the rich households enjoy almost free water in central Mumbai. Low telecom subscription fees to encourage access were compensated with 
Figure 9. Prices and Profits in Telecom Services

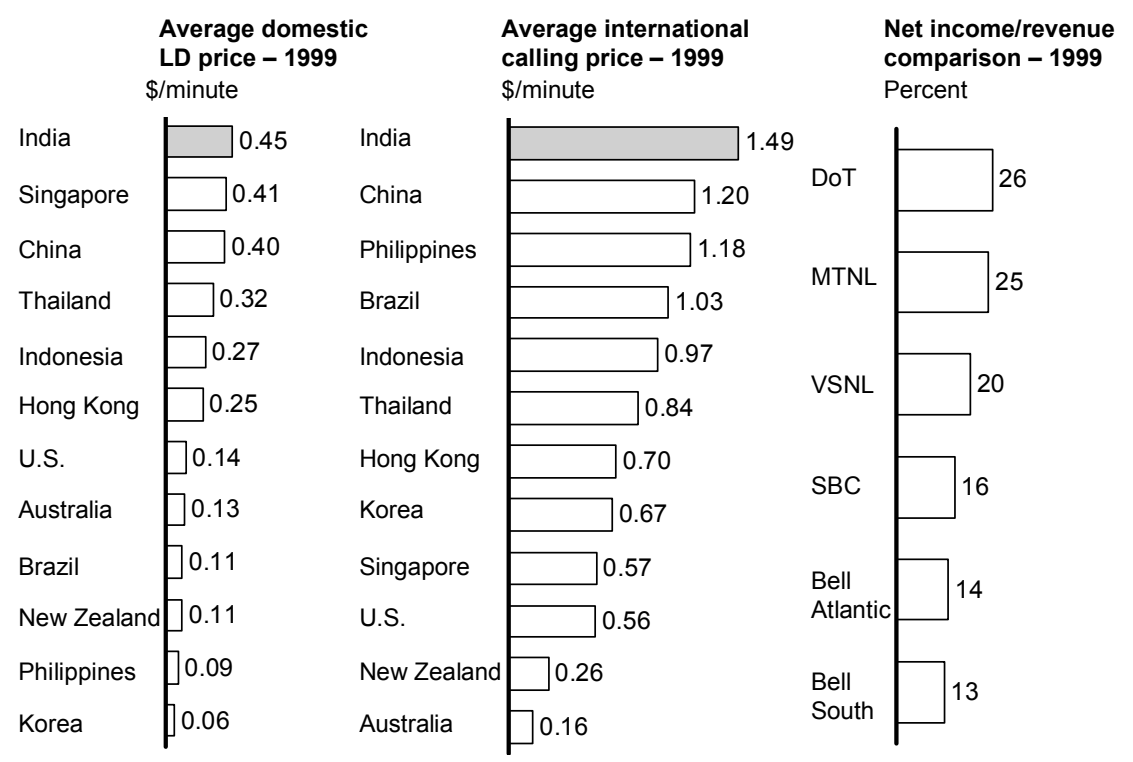

Source: McKinsey Global Institute

Figure 10. Bad Medicine for Japan's Economy Average hospital length of stay for acute care, 1996, days

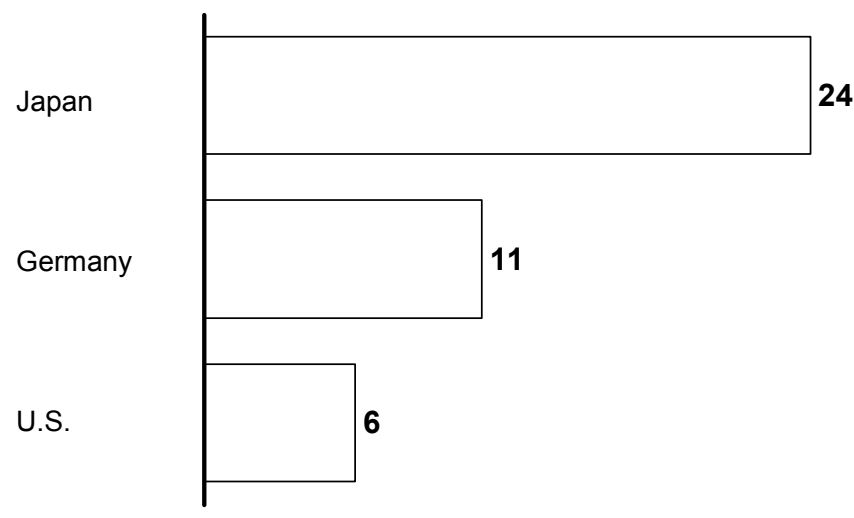


call rates significantly above their marginal cost, resulting in very low network utilization. In the case of Indian telecom, the government has set the prices so high that the Indian State-owned telecom operator is among the most profitable in the world despite its low productivity (Figure 9).

- Social sectors. Socially critical sectors such as health care, education and social housing construction represent up to $20 \%$ of a country's economy. Governments have also tended to own and regulate these "strategic" sectors with most often disastrous results. World Bank research has shown that the lack of accountability of school masters in many Indian primary schools often results in teachers not even showing up for classes, and that the largest part of the government social programs ends up benefiting the middle and upper classes. MGI research found that social housing schemes in Russia lead to low productivity but enable well connected developers to crowd out the new efficient firms. Another example is the Japanese Government's reimbursement scheme in health care, which gave an incentive to hospitals to keep their patients as long as possible, resulting in an average length of stay six times longer than in the US for the same disease (Figure 10).

\section{Land market issues.}

The economic performance of a large share of a country's economy depends crucially on the conditions prevailing in its land market, e.g., the retail, construction, agriculture, hotels and restaurant sectors, and through spillover effects, the wholesale, construction materials and tourism sectors. Land market issues include the following:

- Restrictions on land ownership for foreigners. Many countries (e.g., India and UAE) continue to impose severe restrictions on land ownership by foreigners. This is particularly damaging in the retail and housing construction sectors where land appreciation is a critical component of the investments' financial viability.

- Low property taxes and user charges on utilities. Actual property taxes and user charges are often very low. This does not give local governments the financial means and incentives to develop new land $50 \%$ of local government revenues come from property taxes in the US. This was found to be the main reason that local governments in India were bankrupt and incapable of developing new land much beyond the 1947 city limits. 
Figure 11. Small Stores Are Big in Japan

Share of total hours worked in retailing sector, percent
DCO-ZXE081-20031100-jgfPP 1

Restrictive zoning

laws

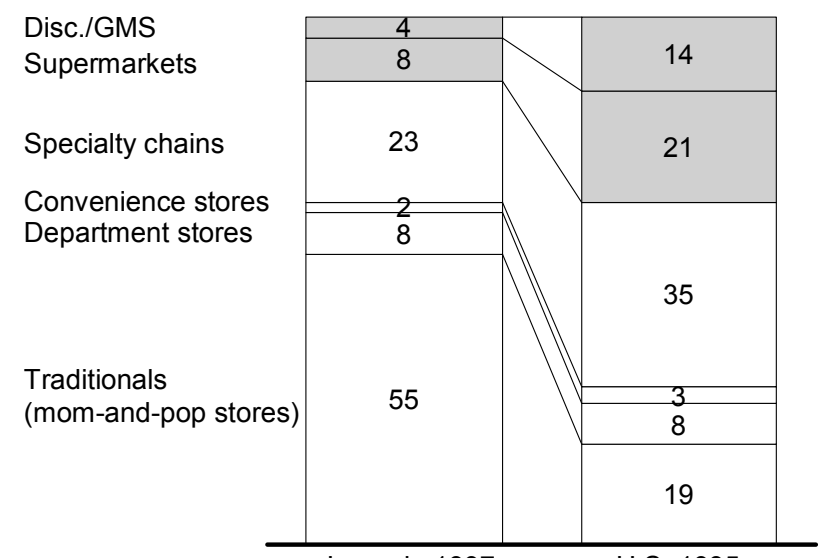

Japan in 1997

U.S. 1995

DCO-ZXE081-20031100-jgfPP1

Figure 12. Impact of Unclear Land Titles on the Indian Retail Sector

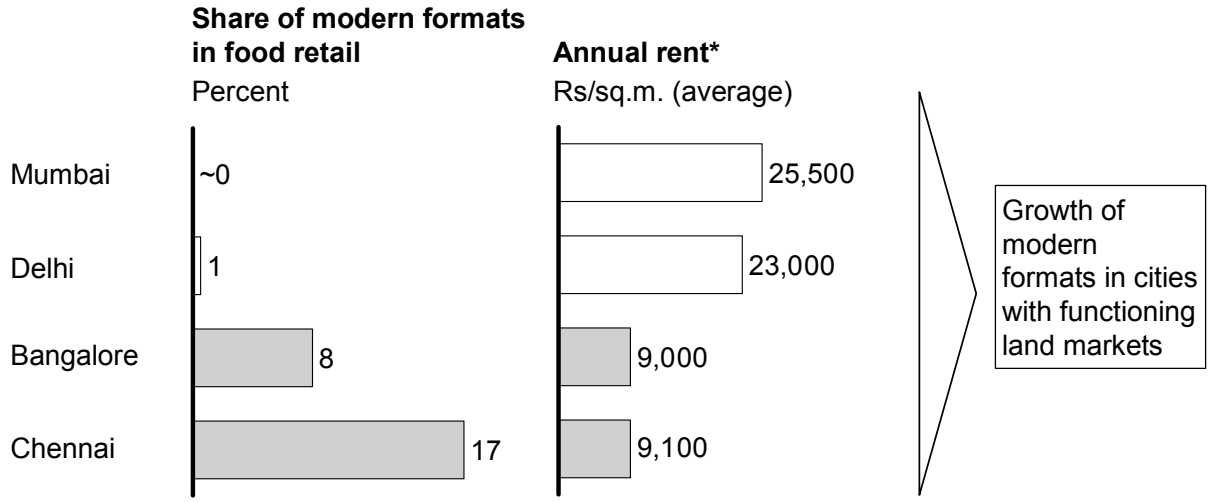

* Central Business District 
- Difficult access to government land. A large extent of prime land remains in the hands of the government or government-owned companies. For example, in Russia, MGI found that prime government land is allocated to friendly business interests in the retail and housing construction sectors through less than transparent mechanisms.

- Restrictive zoning laws. Zoning laws restricting large modern retailers are quite common. For example, in Japan, zoning laws are the reason that half of the employment in the food retail sector is still in low-productivity Mom-and-Pop stores (Figure 11).

- Land-related administrative barriers. MGI and FIAS found in most developing countries multiple layers of land-related administrative red tape to be a major impediment to investments and productivity growth because they lead to multiple delays and inefficiencies.

- Unsecured property rights. Last but not least, unclear land titles combined with unreliable courts limit the supply of land and discourage investments. Southern States in India enjoy much higher land tenure security than the Northern States. This is the main reason for why land market prices are lower and the share of modern retailers is much higher in Southern Indian states (Figure 12).

\section{Unequal enforcement of policies and the informality trap.}

This is probably the biggest and least understood impediment to economic development. Furthermore, this issue tends to get worse as developing country governments keep adding more fiscal and regulatory burdens on companies while their enforcement capacity and governance remain largely inadequate. Informal companies operate fully or partially outside the formal fiscal and legal environment; they tend to be subscale, subinvested and subskilled; and they also tend to produce substandard products and services. Informality has two dire and related economic consequences. First, and this is increasingly being recognized, it creates a trap from which it is very difficult to escape. Many companies have no choice but to be informal because they cannot afford the tremendous cost of becoming formal (e.g., formalizing land property rights typically takes more than 100 administrative steps). This results in valuable human and capital resources being stranded in subscale operations with little access to financing. Second, it distorts the competitive playing field to the advantage of informal companies, 
Figure 13. Unequal Enforcement and the Informality Trap

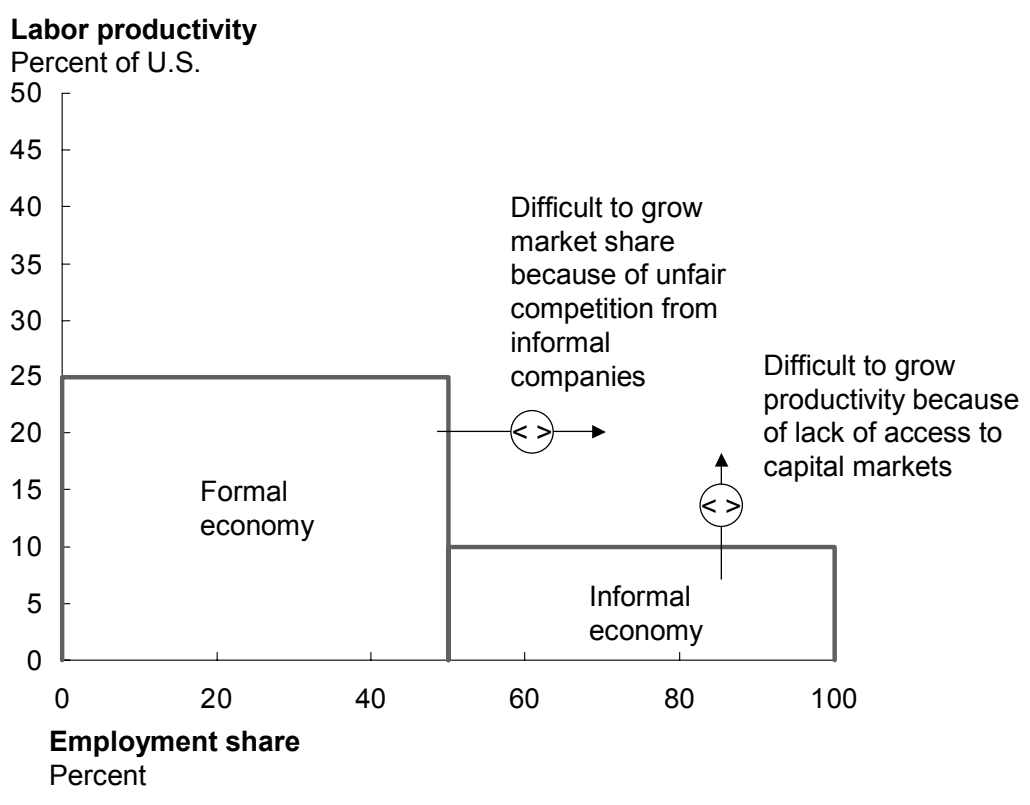

Figure 14. Low Productivity Performance of Large Informal Players

Percent of U.S. productivity

Productivity performance of informal players

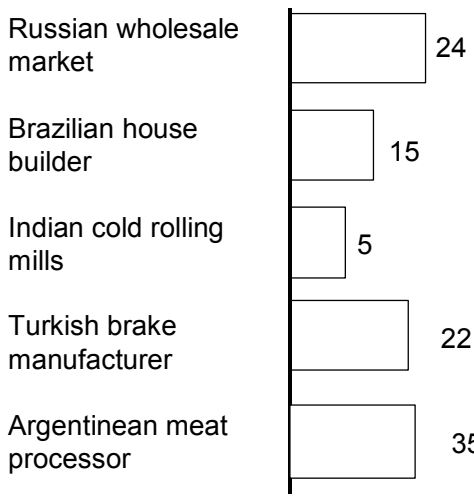

\section{Productivity of formal} competitors

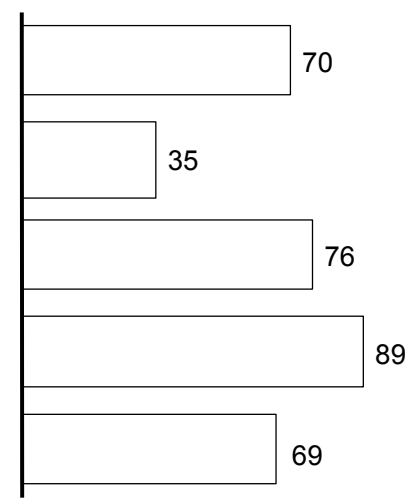


which are on average more than three times less productive than formal ones (Figure 13).

- According to the World Bank and the OIT (Organisation Internationale du Travail), informality typically affects around $40 \%$ of the nonagricultural workforce in middle income countries - this proportion rises to $70 \%$ and above in lower income countries.

- The problem is actually getting worse in most countries as governments keep increasing the fiscal and regulatory burden on companies - often to meet the requirements of the international financial institutions and international treaties (e.g., stricter standards on safety and intellectual property rights). Brazil, for example, has increased its tax burden from $24 \%$ to $30 \%$ of GDP over the last ten years in an attempt to stabilize its public finances. The result has been that informality has increased from $40 \%$ to $50 \%$ of the non-agricultural workforce during that period.

- The rise and negative economic impact of informality goes a long way in explaining the "Washington Paradox", i.e., why the economic performance of most developing countries remained disappointing in the 1990s despite significant progress in implementing recommendations of the "Washington Consensus". In its country studies, the MGI estimated that informality was costing developing countries between one and two percentage points in annual GDP growth. An indirect hint of the significant negative economic impact of informality is the fact that the few countries that became rich (e.g. Japan, Singapore, Taiwan and Korea as well as the Western democracies) never suffered from a serious informality problem (more on this later).

- Informality is not confined to micro enterprises. A large segment of the informal sectors consists of medium-size and sometimes large-size companies that manage to evade all or part of their regulatory and fiscal obligations, most often through connections with high-level government officials. Such large informal companies can thus outcompete their formal adversaries despite being much less productive (Figure 14). 
Figure 15. Main Sources of Informality

\begin{tabular}{|c|c|c|c|c|c|c|}
\hline & Taxes & $\begin{array}{l}\text { Safety/health } \\
\text { standards }\end{array}$ & $\begin{array}{l}\text { Land } \\
\text { regulations }\end{array}$ & Counterfeits & $\begin{array}{l}\text { Labor } \\
\text { regulations }\end{array}$ & $\begin{array}{l}\text { Government } \\
\text { energy }\end{array}$ \\
\hline Retail & $\checkmark$ & & $\checkmark$ & $\checkmark$ & $\checkmark$ & \\
\hline $\begin{array}{l}\text { Housing } \\
\text { construction }\end{array}$ & $\mathrm{n}^{\checkmark}$ & & $\checkmark$ & & $\checkmark$ & \\
\hline $\begin{array}{l}\text { Food } \\
\text { processing }\end{array}$ & & $\checkmark$ & & & & \\
\hline Apparel & $\checkmark$ & & & $\checkmark$ & & \\
\hline Steel & & $\checkmark$ & & & & $\checkmark$ \\
\hline $\begin{array}{l}\text { Consumer } \\
\text { electronics }\end{array}$ & $\checkmark$ & & & $\checkmark$ & & \\
\hline Cement & & & & & & $\checkmark$ \\
\hline Software & & & & $\checkmark$ & & \\
\hline
\end{tabular}

Figure 16. Sanitary Controls and Regulations by Type of Meat-Processing Facility in Argentina

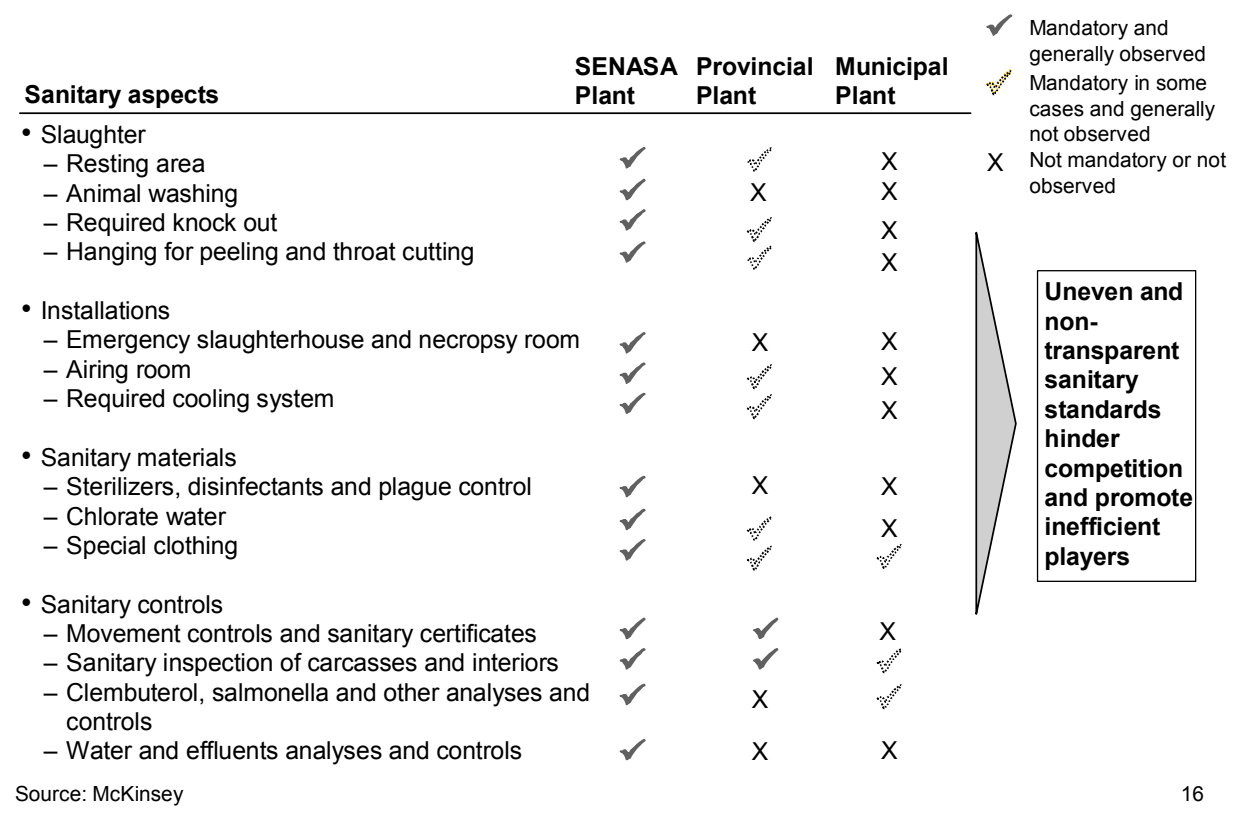


- There are multiple sources of informality and the way it plays out varies significantly by sector (Figure 15):

- Land market regulations. Land market informality has two consequences. First it gives a very important competitive advantage to the informal companies operating on cost-free land, which is critical in the retail, hotels, restaurant and housing construction sectors. Second, it prevents the users of informal land from borrowing against it. Most of the lending to small and medium-size enterprises is done using real estate as the collateral, even in the US today. Hernando De Soto, who has explained the latter effect very well, has also documented in great detail how land informality issues stem from red tape in the land markets. In the Philippines, for example, De Soto estimated that legalizing informal land takes 168 administrative steps with 53 different public and private agencies, and takes between 13 and 25 years ("The Mystery of Capital").

- Labor rules. Most developing countries have put in place relatively generous social security provision and labor rules. The problem is that these obligations are only met by the public sector and best practice formal companies who can afford them, while most workers enjoy no protections whatsoever in the informal sector. The worst case is Brazil, where half of the social security contributions paid by formal companies is used to pay the deficit of the generous public pension system.

- Energy provided by the government. Non-payment of energy (e.g., electricity and gas) is a critical issue in sectors such as steel and cement that are heavy users of energy. This is the reason that obsolete and subscale plants survived in Russia and India. Nonenforcement of energy liabilities is a major source of implicit industrial subsidy - it costs the Indian government 1.5\% of GDP.

- Sector specific policies. We have already mentioned the case of Middle Eastern merchants who were able to go around the fat margins of monopolist import agents by relying on "parallel" imports. Evasion of import tariffs and product standards has also been an issue in the retail, food processing, auto part, consumer electronic and software sectors. For example, uneven and nontransparent sanitary standards favor informality in the Argentinean meat-processing sector (Figure 16). 
Figure 17. Unequal Enforcement of Taxes and Tariffs in the Russian Retail Sector

Indexed to price in Russian groceries $=100$

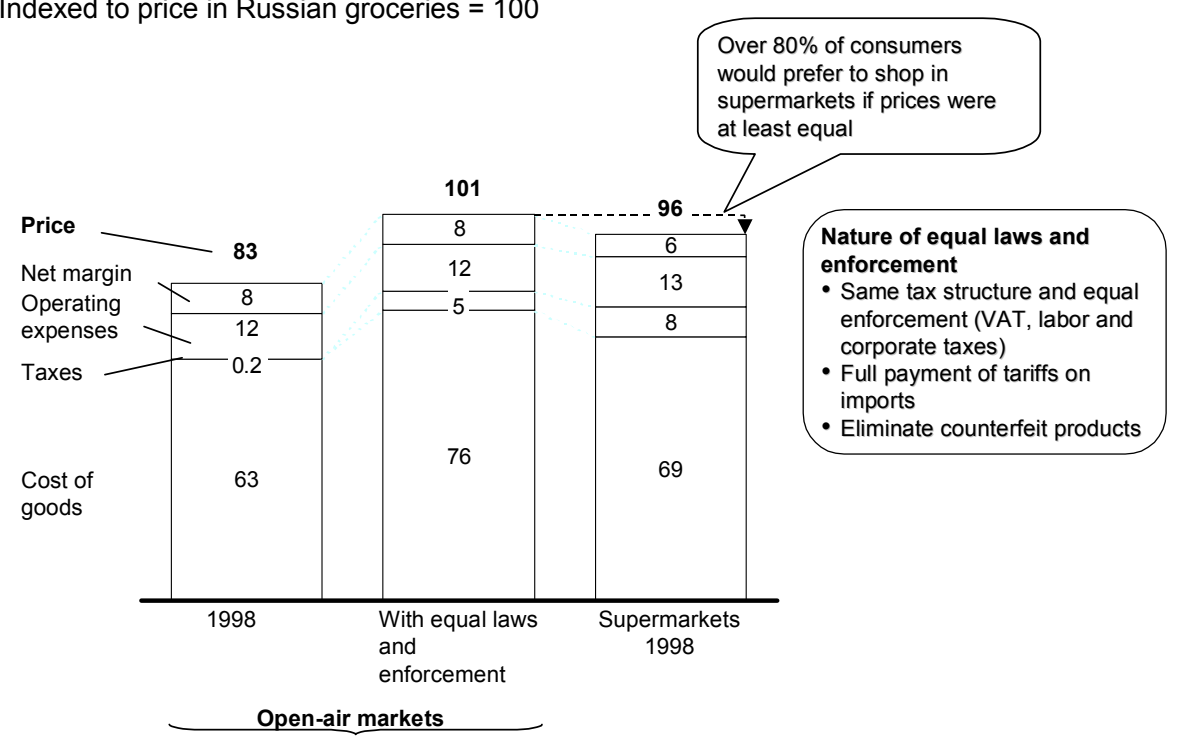

Source: McKinsey Global Institute

Figure 18. Advantages of Tax Evasion in Single-Family Housing in Argentina

Sale price $=100$

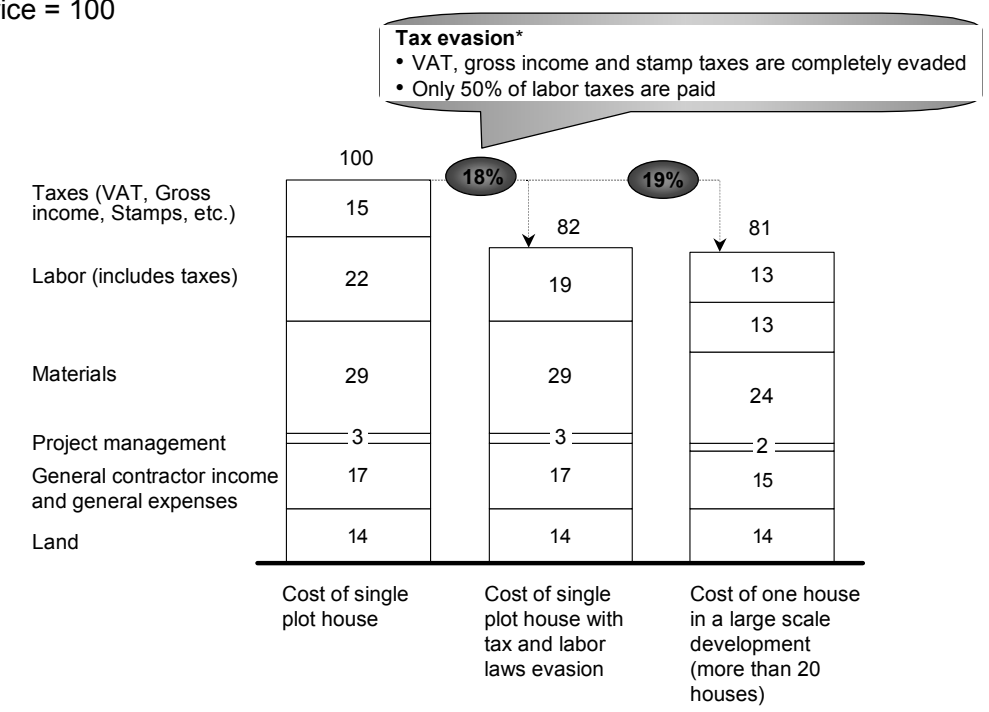

* These assumptions are related to the common industry practice of paying the workers a declared income equal to the minimum agreed salary and with the high level of evasion observed in the other taxes 
In other cases, the government is imposing too strict safety and health standards given the economic development of the country, e.g., it would be safer for Indian families to drive in cheaper cars with relaxed safety standards than to be forced to transport the whole family on the motorcycle. The imposition of rich country product standards thus often results in a dual market segmentation developing country consumers are often left with the choice between quality but expensive products and services, and low quality informal products, which are still relatively expensive because they are produced through informal methods. Lower product market standards and trade barriers between developing markets would make it more attractive and cost effective to design and produce products and services specifically targeted at low-income consumers. This lagging opportunity is evidenced by the fact that South South FDI is increasing rapidly enabling the development and spread of low spec products produced with state of the art methods e.g. Chinese companies know how to produce $\$ 50 \mathrm{TVs}$ in Vietnam.

- Taxes. Last but not least, tax related informality affects most industries and can lead to a very significant cost advantage. Retail and housing construction have been among the sectors most affected by tax related informality. For example, Russian open wholesale markets enjoy $20 \%$ lower prices than supermarkets by evading most of their tariff and tax obligations (Figure 17); and unequal tax enforcement favors low productivity players in the Argentinean construction sector (Figure 18).

As discussed earlier, the tax burden on formal companies is high and getting higher. Developing countries typically collect more than $25 \%$ of GDP in taxes, and about $80 \%$ of these taxes are collected from formal companies as VAT, corporate and labor taxes. Personal and property tax collection is usually very small. Developed countries typically also have a tax burden of around $30 \%$ of GDP, but only half is collected from companies. Furthermore, this tax burden increased slowly over time, giving developed countries the time to develop effective tax administrations. The tax burden on the economy was less than $10 \%$ of GDP when developed countries were at the economic development level of Brazil today. The reasons that the tax burden is so much higher today include high interest payments, large and often non targeted and non effective social 
Figure 19. High Fiscal Burden Due to Ineffective Government Programs

Total government expenditures as \% of GDP

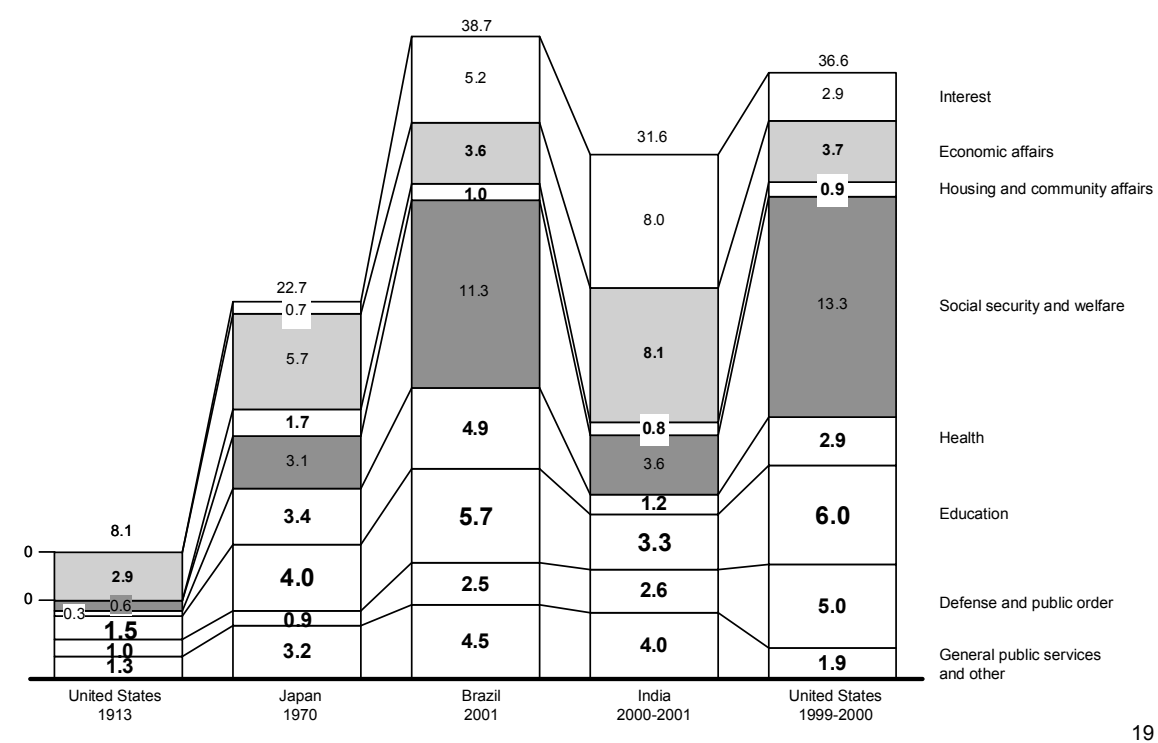

Figure 20. Microeconomic Reform Would Contribute to Macroeconomic Stability

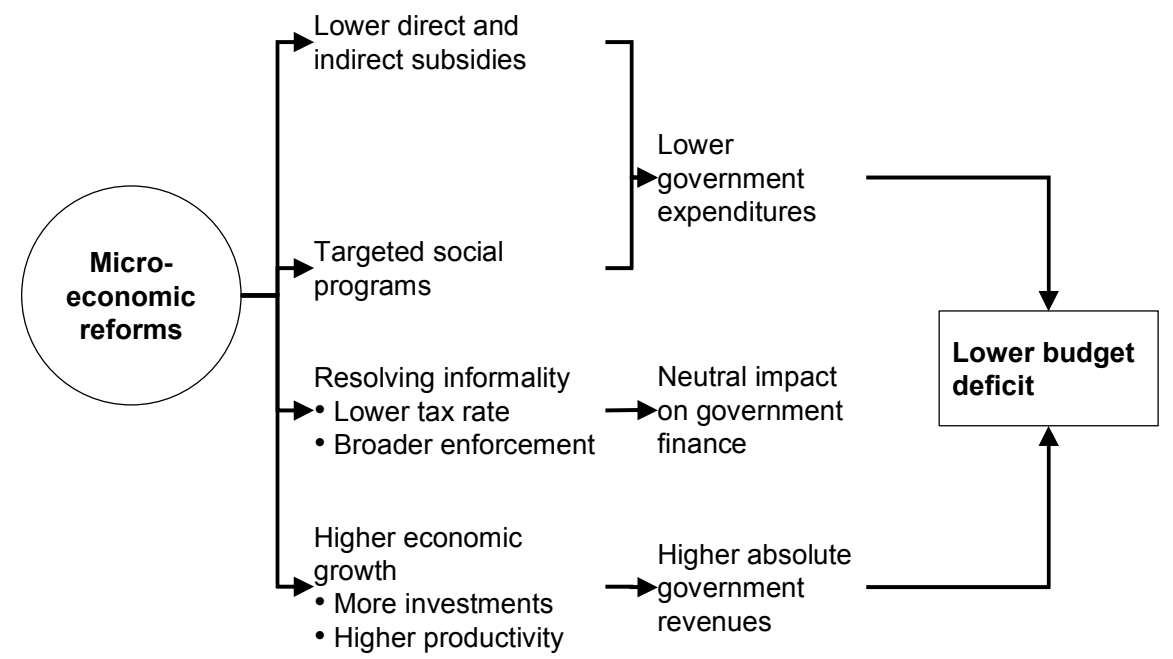


programs, large spending on defense, large spending on government administration, large amount of explicit or implicit industrial subsidies, large amounts spent on social security and large amount of illicit appropriations. Japan has shown that large public investments could be made in education, health care and infrastructure with a reasonable tax burden (Figure 19).

The higher the tax and regulatory burden, the less likely the government administration and courts are going to be capable or even willing to enforce the rules on every company. The problem is made worse by lack of resources, lack of skills, poor organization (e.g., no specialized commercial judges) and by the lack of transparency and accountability leading to corruption in the government and judiciary. The first step in reducing informality has to be reducing the regulatory and fiscal burden.

Addressing these microeconomic issues will also contribute to resolving macroeconomic issues (Figure 20). For example, reform of the electricity sector in India would enable the federal government to reduce its budget deficit by one and a half percentage points of GDP, which is the amount currently paid to State governments to compensate for the $40 \%$ of the electricity not paid for.

\section{METHODOLOGY OF THE McKINSEY GLOBAL INSTITUTE}

These findings are based on the systematic analysis of the barriers to productivity and investment growth in a representative sample of sectors for each studied country.

The focus is on productivity and investment because they are the key engines to economic growth. The productivity level at which the labor and capital inputs are put to work is the primary driver of GDP per capita.

In effect, every time a company increases its productivity, it generates an economic surplus, which can then be redistributed to consumers in the form of better products and/or lower prices, to employees in the form of higher salaries and/or to investors in the form of higher profits to be reinvested by the most productive companies.

Most of the work is conducted at the economic sector level because the relative importance of factors can only be firmly established at the microeconomic level, where causality links can be conclusively determined. It is also only at the sector level that deeply buried micro policy issues can be identified and analyzed. 
Figure 21. Methodology and Information Sources for Sector Analysis

\begin{tabular}{|c|c|c|c|c|}
\hline & Step 1 & Step 2 & Step 3 & Step 4 \\
\hline & $\begin{array}{l}\text { Productivity } \\
\text { benchmarking }\end{array}$ & $\begin{array}{l}\text { Operational issues } \\
\text { explaining } \\
\text { productivity gaps }\end{array}$ & $\begin{array}{l}\text { Lack of competitive } \\
\text { pressure on managers } \\
\text { to improve }\end{array}$ & $\begin{array}{l}\text { Policy issues } \\
\text { affecting } \\
\text { competition }\end{array}$ \\
\hline Analysis & $\begin{array}{l}\text { - Output measures } \\
\text { - Physical } \\
\text { - Value added } \\
\text { - Input measures } \\
\text { - Hours worked } \\
\text { - Physical units of } \\
\text { capital } \\
\text { - International } \\
\text { benchmarks }\end{array}$ & $\begin{array}{l}\text { - Excess workers } \\
\text { - Organizational issues } \\
\text { - Labor trainability } \\
\text { - Scale issues } \\
\text { - Lack of viable } \\
\text { investments } \\
\text { - Lack of innovation }\end{array}$ & $\begin{array}{l}\text { - Lack of exposure to } \\
\text { global best practice } \\
\text { - Non level playing field } \\
\text { - Analysis of prices and } \\
\text { profitability } \\
\text { - Analysis of entries/exits } \\
\text { - Comparison of cost } \\
\text { structure and } \\
\text { government liabilities }\end{array}$ & $\begin{array}{l}\text { - Reasons for lack of } \\
\text { competition } \\
\text { - Micro policy restrictions } \\
\text { - Unequal enforcement } \\
\text { - Factors directly affecting } \\
\text { operations } \\
\text { - Labor skills } \\
\text { - Infrastructure/clusters } \\
\text { - Access to finance }\end{array}$ \\
\hline $\begin{array}{l}\text { Information } \\
\text { sources }\end{array}$ & $\begin{array}{l}\text { - Official statistics } \\
\text { - Company/consumer } \\
\text { surveys } \\
\text { - Past studies } \\
\text { (international } \\
\text { benchmarks) }\end{array}$ & $\begin{array}{l}\text { - Analysis of a sample } \\
\text { of companies } \\
\text { operations } \\
\text { - In-depth interview } \\
\text { with best practice } \\
\text { companies }\end{array}$ & $\begin{array}{l}\text { - Financial data } \\
\text { - Price surveys } \\
\text { - Evolution of market } \\
\text { shares } \\
\text { - Trade/FDI flows }\end{array}$ & $\begin{array}{l}\text { - Interview with best } \\
\text { practice companies } \\
\text { - Interview with } \\
\text { government officials }\end{array}$ \\
\hline
\end{tabular}




\section{Conducting Industry Level Analysis}

The barriers to higher productivity and investments are analyzed for each sector through a four-step process, which relies on extensive data gathering and company interviews (Figure 21).

If Assessing productivity performance. The first step consists of measuring the productivity performance gaps between the studied country and relevant benchmark countries for the sector under investigation. It starts with a comparison of the labor productivity levels complemented, for the capital intensive sectors, by a comparison of the capital productivity levels. The level of productivity growth is estimated to assess whether the studied country is rapidly closing its productivity gaps which would typically be the case if the barriers to productivity growth had been recently removed. A "physical" definition of productivity was used, i.e., the number of hours of work needed to assemble a car (adjusted for quality and differences in vertical integration), moving away from measures based on financial data, which in most cases prevent meaningful international comparisons in the absence of value-added, purchasing power parity exchange rates. In many sectors, especially for developing countries, the lack of reliable sector level statistics made it necessary to estimate productivity levels through interviews/surveys of a sample of representative companies. In India, for example, MGI had to interview 614 companies. Actual productivity levels are benchmarked between countries using output (physical measures adjusted for quality or value added adjusted using purchasing power parities) and input (hours worked, units of physical capital) measures. The methodologies used to measure service sector outputs were first developed in the context of industrial countries before being adapted to developing countries. The detailed methodologies used are discussed in the appendices of the sector case studies (see www.mckinsey.com/mgi).

I Understanding the operational reasons for the productivity gaps. The second step consists of explaining the productivity level gaps at the operational level. The productivity gaps are systematically allocated between all factors of production, i.e., level of capital investments, scale of operations, modes of organization, labor skills, supplier relations, product/service quality, etc. For developing countries in particular, the share of the labor productivity gap, explained by the fact that the cost of labor is cheaper relative to capital when compared to developed countries, is carefully calculated. This is the reason that managers in the Indian wheat milling sector, for example, unlike their US counterparts, do not 
automate packaging. The economics literature typically expects this effect to be the dominant explanation of the productivity gaps - the MGI found it to be relatively unimportant, even in a country with very low labor costs such as India (Figure 4). This analytical step defines the productivity potential/ frontier for each sector of the studied country, taking into account factor cost differences. The productivity difference between the actual productivity level and the productivity potential/frontier is the gap managers should be able to fill. The next two analytical steps discussed below identify why that has not happened. We first discuss in more detail how the operational gap analysis has been conducted.

- Assessing productivity performance by type of players, starting with the local best practice. The most effective way of conducting this analysis is to identify and interview the likely best practice companies (i.e., companies with the highest levels of total factor productivity) in the sector within the country under study. These companies are typically easy to identify (e.g., large subsidiary of best practice multinational). Using quantitative analysis and extensive interviews, the first step is to establish productivity level of the local best practice players as compared with international best practice. The next step is to understand the operational reasons for these productivity gaps through expert interviews and plant visits. A similar process was followed to explain the productivity gaps between the local best practice firms and the local average. The best practice firms usually have a very good perspective on the nature of their operational advantages against local competitors, which can then be confirmed through additional interviews with average local companies.

- Conducting analysis and interviews. Local best practice firms tend to be relatively easy to access and engage because the findings are likely to serve their interest, and because they tend to be naturally interested in understanding how their productivity compares with international best practice as well as with their local competitors. They are also a great source of information on the external factors limiting their productivity and/or limiting them from expanding/putting competitive pressure on their less productive local competitors. This is not true of the average-firm managers, who tend to blame their poor productivity on everything but themselves, e.g., the workers have poor skills, the infrastructure is terrible and the taxes are too high. This benchmarking approach sorts these things out, i.e., why does the company next door, confronted with the same infrastructure issues and 
recruiting from the same labor pool, manage three times higher productivity levels?

I Assessing competitive pressure. The third step is the analysis of the sector's competitive dynamics and the extent to which they put managers under pressure to reach their productivity potential. The extent to which companies at different levels of productivity compete with each other is determined, as well as the extent to which the competition is fair. For example, to what extent are domestic incumbents exposed to global best practice companies, whether through trade or foreign direct investments. Other symptoms of competitive intensity are analyzed beyond manager interviews, which can be very subjective if not misleading (managers tend to overestimate the extent to which they compete). These include shifts in market shares, the degree to which there are new entrants as well as companies exiting or going bankrupt, evidence of price-based competition and profitability levels. This is a crucial analytical step since most managers take significant corrective actions with respect to their company's productivity performance only if they are under the threat of financial losses/bankruptcy brought about from having to compete (fairly) with significantly more productive competitors.

If Assessing the importance of external factors in explaining managers' behavior and companies' poor productivity. The last step reaps the fruits of the hard won findings from the first three steps. It consists of systematically linking the factors in the external environment of companies (e.g., labor and capital market regulations, infrastructure, macroeconomic conditions, etc.) to the different types of operational deficiencies that build up to the overall productivity gaps. These external factors can lead to lower productivity either directly (e.g., labor rules preventing lay-offs equally enforced on all type of companies) or by preventing full and fair competition with global best practice companies (e.g., ban on foreign direct investment in the Indian retail sector). Sectorspecific policy issues have been found to be by far the most important external factors. This is because weak competitive environment conditions were the most important reason that managers are not "pushed" to reach their productivity potential - and sector-specific regulatory issues typically are, among all external factors, the key determinant of competitive conditions (e.g., entry barriers in the form of import tariffs or unequal enforcement of 
Figure 22. Blue Collar Trainability in Housing Construction

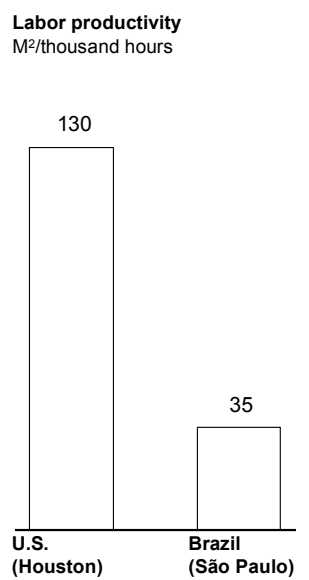

Construction cost

U.S. $\$ / M^{2}$

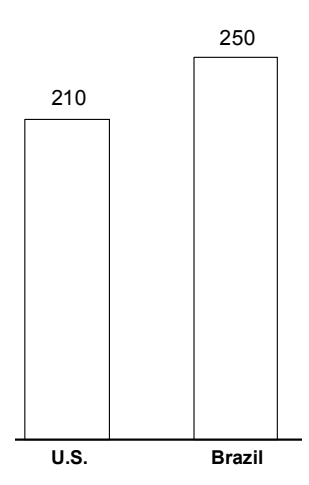

Construction description

\begin{tabular}{|c|c|c|c|}
\hline U.S. & Brazil & & \\
\hline - $75 \mathrm{M}^{2} / \mathrm{unit}$ & $\cdot 40 \mathrm{M}^{2} / \mathrm{u}$ & & \\
\hline •209 units & -20 units & & \\
\hline •1 floor & - 5 floors & & \\
\hline -Content & -Content & & \\
\hline-1 bedroom & $-1-2 b$ & edroom & \\
\hline & -1 bath & oom & \\
\hline bathroom & - No int & inal & \\
\hline$-A C$ & doors & & \\
\hline Organization of $\mathrm{I}$ & bor & & \\
\hline & U.S. & Brazil & Brazilian gap \\
\hline Subcontractors & 40 & 10 & $\begin{array}{l}\text { - Less } \\
\text { specialized }\end{array}$ \\
\hline $\begin{array}{l}\text { Blue collar } \\
\text { background }\end{array}$ & $\begin{array}{l}\text { Mexican } \\
\text { agriculture }\end{array}$ & $\begin{array}{l}\text { Brazilian } \\
\text { northeast } \\
\text { agriculture }\end{array}$ & $\begin{array}{l}\text { - Similar } \\
\text { educational } \\
\text { background }\end{array}$ \\
\hline
\end{tabular}

Figure 23. Estimating the Impact of Reforms on GDP Growth

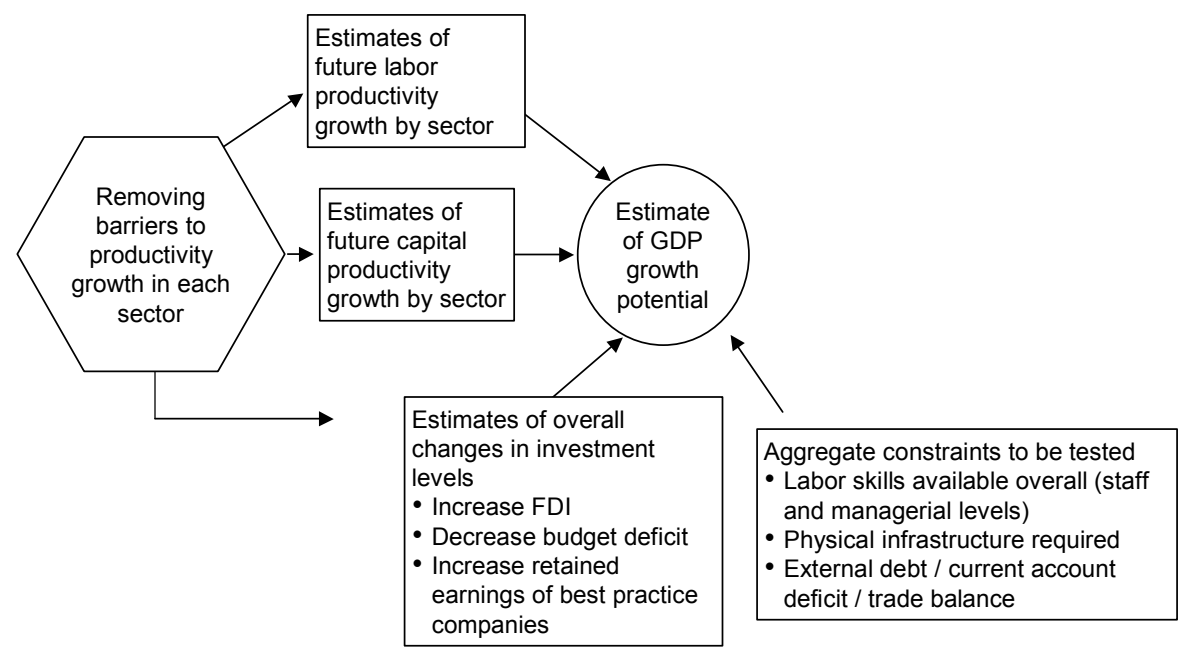


sanitary regulations favoring the local low productivity incumbents in Argentina's meat processing sector). In Brazil, housing construction developers were blaming their poor productivity performance on the low education level of their workers. MGI informed them that housing construction companies in Houston, Texas were achieving best practice productivity levels with illiterate ex agricultural workers from Mexico (Figure 22).

In short and not surprisingly, the last thing most managers will mention are the sector-specific policy issues that shield them from having to compete on equal terms with more productive companies.

\section{Synthesizing the Findings across Sectors}

Country-wide conclusions can be derived from the analysis of productivity barriers across a representative sample of economic sectors combined with a few targeted aggregate analyses. It is possible to derive rough estimates of what would be the additional economic growth such reforms would yield as well as to identify the employment sensitivities of such reforms. These aggregate analyses, combined with the sector-specific finding, are invaluable in helping governments set priorities (e.g., in Russia, Korea and India), convince a critical mass of reform opponents and identify the areas/sectors where targeted demand side social policies will be the most needed to accompany the economic reforms.

These estimates, grounded on a comprehensive microeconomic fact base, are fundamentally different from classic macroeconomic projections, which have been proven wrong more often than not and as a result largely discredited. For example, traditional macroeconomic projections typically assume a constant evolution in the capital to output ratio combined with some forecast of future investment levels. These analyses fail to recognize the potential that exists in most developing countries for very significant increases in capital productivity that would take place if companies were subject to full competitive forces. They also fail to identify the key microeconomic drivers of investment growth, which are fundamentally related to the drivers of productivity growth. Finally they ignore the fact that microeconomic reforms would have a large positive effect in helping governments improve macroeconomic conditions and overall investment levels by improving the fiscal balances.

The key analytical steps of the overall approach followed to move from sector specific conclusions to economy wide implications are as follow (Figure 23): 
I The first step is to estimate the impact of removing productivity barriers on future labor and capital productivity growth for each of the studied sectors. This is done by analyzing what happened in other countries that went through similar sectoral reforms (e.g., how fast modern retail formats grew in Thailand, Poland and China after the opening of their retail sectors to foreign retailers).

I The next step is to extrapolate these findings to the other non-studied sectors based on microeconomic analogies. For example, the findings from the retail sector can be extrapolated to the wholesale, restaurants and hotel sectors. Similarly, the findings from the steel sector can be extrapolated to most heavy manufacturing sectors such as cement or aluminum. This allows us to estimate the overall economy wide productivity growth potential and to identify the key reforms necessary for overall productivity growth.

II Reforms in the labor market may also be necessary to increase labor inputs. For example, MGI estimated that France could increase its labor inputs by $1 \%$ a year by increasing the incentives for people to work.

I Since the key aggregate constraint for developing countries is the overall level of private business investments, it is also necessary to understand by how much investment levels could increase from removing the barriers to sector level productivity growth, as well as from additional reforms in the capital markets needed to increase savings and efficiency of capital allocation between sectors and companies. For example, MGI estimates showed that in India, removing the micro barriers to productivity growth would allow the government to quickly balance the budget (allowing domestic private investment to increase by $4 \%$ of GDP) and attract an additional $2 \%$ of GDP in foreign direct investments. MGI also found that widespread increases in competition together with the privatization of the banking system and capital intensive utility sectors would increase capital productivity in India by more than 50\%. These estimates for investment and capital productivity growth yielded for India a 7\% GDP/capita growth potential (as compared with $3 \%$ currently).

I So the combination of capital productivity and investment growth estimates yields a GDP growth potential for developing countries. In the case of developed countries, the GDP growth potential is derived from the labor productivity and employment growth estimates.

9 There are a few other important aggregate constraints to test for in the case of developing countries. As was the case for investments, MGI found 
that even in India and Brazil, removal of the sector level productivity barriers would go a very long way in accommodating these aggregate constraints. The first constraint entails an estimate of the future investment requirements in infrastructure needed to accommodate the growth potential. The second is an analysis of the future evolution in the balance of trade taking into consideration higher export potential due to higher productivity (e.g., the apparel sector in India) as well as increased import requirements on machines and equipment to sustain the higher investment levels. The third constraint analysis is an estimate of the aggregate demand for workers with higher degrees of education. This is based on a detailed understanding of the skills required to achieve the productivity potential in each sector studied. These analysis did increase the relative overall importance of infrastructure, labor and capital markets but, surprisingly, sector level microeconomic reforms remained at the top of the list for all the developing countries studied.

Finally, these in-depth microeconomic analyses of sectors, combined with top-down country-level benchmarking, can give important insights into employment issues. Given the estimate of the overall GDP/capita growth potential, it is possible to derive sector-specific output growth. Although this seems like an impossible task given the complex web of interactions that link one sector's output to another's (what economists refer to as general equilibrium effects), MGI found a way to crack through this problem by relying on the natural experiment of countries at different stages in their economic development. This is based on the observation that regardless of race, religion or culture, consumers tend to follow similar consumption patterns as income grows. So, for a given country, economists can map sectoral growth by observing what happened in countries further ahead in their economic development. Sector-specific labor productivity growth estimates can then be combined with these sector-specific output growth estimates to shed new light on the future evolution of employment for each economic sector.

As we move from the microeconomic diagnostic of a sample of industries to making economy wide recommendations, it is thus very important to take into account general equilibrium effects. The good news is that finding ways to improve total factor productivity in a given sector is always a good thing for the economy because it generates a surplus that can then be redistributed. The argument should be on how to redistribute it, as opposed to how to create it. In theory at least, it should always be possible to use part of this surplus to address some of the social issues that might result from productivity growth. This should be done without overly distorting the markets, e.g., through targeted demand side social policies. 
Figure 24. Summary of Micro-Policy Issues

\begin{tabular}{|c|c|}
\hline Poor micro-economic policies & $\begin{array}{l}\text { Unequal enforcement of } \\
\text { micro-economic policies }\end{array}$ \\
\hline $\begin{array}{l}\text { - High import tariffs and duties } \\
\text { - Non-tariff trade barriers (e.g., cumbersome } \\
\text { technical requirements) } \\
\text { - Restrictions to FDI } \\
\text { - Licensing (e.g., agency law) } \\
\text { - Pricing/product/service limitations (e.g., short } \\
\text { opening hours) } \\
\text { - Lack of intellectual property rights } \\
\text { - Strict zoning laws (e.g., restrictions on large } \\
\text { - Scale stores) } \\
\text { - Pubsidies (e.g., cheap energy) } \\
\text { (e.g., water distribution) } \\
\text { - Poor regulation of social sectors }\end{array}$ & $\begin{array}{l}\text { - Customs (e.g., smuggled goods) } \\
\text { - Counterfeits } \\
\text { - Evasion of sanitary and safety rules } \\
\text { - Non-payment of government liabilities } \\
\text { - Energy } \\
\text { - Transport } \\
\text { - Taxes } \\
\text { - Unfair access to government } \\
\text { assets } \\
\text { - Bank loans } \\
\text { - Procurements } \\
\text { - Land } \\
\text { - Key infrastructure } \\
\text { - High cost of becoming formal } \\
\text { - Lack of independent legal recourse }\end{array}$ \\
\hline $\begin{array}{c}\text { Formal companies not exposed to } \\
\text { best practice }\end{array}$ & $\begin{array}{l}\text { Non level playing field and } \\
\text { informality trap }\end{array}$ \\
\hline
\end{tabular}

\section{Figure 25. Unintended Consequences of Supply Side Social Policies}

\begin{tabular}{|c|c|c|c|}
\hline Micro policy issues & Social intentions & $\begin{array}{l}\text { Unintended } \\
\text { consequences }\end{array}$ & Solution \\
\hline $\begin{array}{l}\text { - Restriction to FDI/ } \\
\text { tariffs/quotas }\end{array}$ & $\begin{array}{l}\text { - Protect national } \\
\text { champions } \\
\text { - Protect existing jobs }\end{array}$ & $\begin{array}{l}\text { - National champions } \\
\text { becoming hopelessly non } \\
\text { competitive } \\
\text { - Net loss of output and } \\
\text { eventually jobs }\end{array}$ & $\begin{array}{l}\text { - Remove restrictions } \\
\text { - Support workers not } \\
\text { companies }\end{array}$ \\
\hline $\begin{array}{l}\text { Non enforcement of laws } \\
\text { on informal players }\end{array}$ & - "Give a break to the poor" & $\begin{array}{l}\text { - Lock the poor into the } \\
\text { informality trap }\end{array}$ & $\begin{array}{l}\text { - Reduce requirements to } \\
\text { become legal } \\
\text { - Legalize informal } \\
\text { companies and workers } \\
\text { - Improve enforcement }\end{array}$ \\
\hline - High minimum wage & $\begin{array}{l}\text { - Increase income of low- } \\
\text { skilled }\end{array}$ & $\begin{array}{l}\text { - Trap them in } \\
\text { unemployment and/or } \\
\text { informality }\end{array}$ & - Earned income tax credit \\
\hline - Small-scale reservation & $\begin{array}{l}\text { - Create jobs in } \\
\text { manufacturing }\end{array}$ & $\begin{array}{l}\text { Underdeveloped sector } \\
\text { because not competitive } \\
\text { in export markets }\end{array}$ & - Remove restriction \\
\hline $\begin{array}{l}\text { - User charge subsidies on } \\
\text { water }\end{array}$ & $\begin{array}{l}\text { - Make water available to } \\
\text { everybody }\end{array}$ & $\begin{array}{l}\text { - No investment in water } \\
\text { services }\end{array}$ & - "Charge for it" \\
\hline $\begin{array}{l}\text { - State financing of } \\
\text { university education }\end{array}$ & $\begin{array}{l}\text { - Provide university } \\
\text { education to the poor }\end{array}$ & $\begin{array}{l}\text { - Subsidize university } \\
\text { education of the rich } \\
\text { - Starve primary education } \\
\text { of much needed } \\
\text { resources }\end{array}$ & $\begin{array}{l}\text { - Raise tuition } \\
\text { - Provide need-based } \\
\text { grants and loans for low } \\
\text { income students }\end{array}$ \\
\hline $\begin{array}{l}\text { - Low telecom subscription } \\
\text { fee and high call charges }\end{array}$ & $\begin{array}{l}\text { - Provide telecom access to } \\
\text { poor people }\end{array}$ & $\begin{array}{l}\text { - Low network utilization } \\
\text { especially by the poor }\end{array}$ & $\begin{array}{l}\text { - Economic pricing } \\
\text { - Subscription subsidiary } \\
\text { for the poor }\end{array}$ \\
\hline
\end{tabular}




\section{CONCLUSION}

Micro policy issues affecting competition have proven to be, collectively, the biggest barriers to economic growth in all the developing countries studied by MGI. These policy issues come in many different shapes and forms (Figure 24).

Most developing countries are only slowly improving their microeconomic policies, while enforcement/informality tends to get worse.

So why is so little progress being made on these critical microeconomic issues? An important reason is that governments do not realize that collectively these issues are the most important barriers to growth. They also often do not realize that many of these market distortions, left in place in the name of social objectives, more often than not lead to much worse social outcomes and/or that there are more market friendly methods of conducting social policies (Figure 25).

Finally, attached to each market distortion, there is inevitably a strong vested interest that will lobby hard for the status quo. Although it may not be enough, experience has shown that the public disclosure of such sector level analysis can go a long way in stimulating countries to reform. This is what happened in the case of restricting FDI in the Indian retail sector. Detailed sector level analysis was necessary to dispel three misconceptions the Indian government had about retail and to initiate a serious debate on the issue. First, the analysis showed that modern retail formats were not only catering to the rich - the price of basic food products would be cheaper in best practice supermarkets if taxes were enforced equally across formats. Second, letting in best practice (foreign) retailers would not result in a reduction in employment - employment in the retail sector has increased in every country studied, together with the share of productive modern formats because retail consumption increased faster than productivity. Finally, the retail sector is not an unimportant low-tech economic sector - retail accounts for more than $10 \%$ of GDP and sophisticated retailers are forcing operational improvements among wholesalers and suppliers as well as becoming export channels in their own right (e.g. Tesco in Thailand and Wal-Mart in Brazil). The Indian government announced in February 2005 that it will authorize FDI in retail.

Governments and international financial institutions should thus leverage much more industry level analysis to identify and remove the microeconomic binding constraints to product market competition and, thus, to economic growth. 